\title{
O ESTADO DE BODIN NO ESTADO DO HOMEM RENASCENTISTA'
}

\author{
Rodrigo Bentes Monteiro \& Walter Marcelo Ramundo \\ Depto. de História da Universidade Federal Fluminense
}

\section{Resumo}

Interessa-nos entender Os Seis Livros da República de Jean Bodin de modo mais sensível a sua época, no tocante à historiografia sobre o homem renascentista e o Estado moderno. O que torna política uma teoria das relações sociais não são apenas as referências a partidos ou governos, mas as estruturas e dinâmicas do poder e da autoridade. Em Bodin essas percepções têm a família como cerne, entendida como instituição social plena de afetos, e como arena de lutas. Consideramos também o universo cultural específico com o qual a obra dialoga, destacando a influência do neoplatonismo.

\section{Pallavras-Chave}

Jean Bodin • Renascimento • Estado moderno • Neoplatonismo

\section{Abstract}

The aim of the article is to understand Jean Bodin's The Six Books of the Commonwealth in a manner sensitive to its time, with regard to the historiography of Renaissance man and of the modern State. His approach to social relations becomes a political theory not only because of references to parties or governments, but rather because of his discussion of the structures and dynamics of power and authority. The family lies at the core of Bodin's perceptions, understood as a social institution that is both replete with emotion as well as a sphere of conflict. The authors also take into account the specific cultural universe with which the work interacts, emphasizing the influence of neo-platonism.

\section{Keywords}

Jean Bodin • Renaissance • Modern State • Neo-platonism

\footnotetext{
${ }^{1}$ A origem da pesquisa encontra-se no estágio pós-doutoral desenvolvido por Rodrigo Bentes Monteiro no Depto. de História/USP entre 2001 e 2002, sob supervisão do Prof. Dr. Modesto Florenzano (a quem agradecemos pela leitura crítica deste artigo), com bolsa FAPESP. Ela prossegue no Depto. de História/UFF, onde se prepara com os bolsistas de iniciação científica (CNPq) Walter Marcelo Ramundo e Wagner Leal Carneiro a tradução do Livre I de Les Six Livres de la République, de Jean Bodin.
} 
O Homem é o que ele acredita (Anton Tchécov)

\section{Homem renascentista}

Nos tempos medievais, renascer era empregado com valor religioso de se “conhecer uma nova disposição de amor", como uma vegetação que cresce novamente, ou ainda em alusão ao mito da fênix. Da mesma forma, o termo renascimento associava-se à "regeneração espiritual", fazendo crer na reencarnação do amor após a morte. No século XVII, a palavra renascença ainda era utilizada como referência ao ressurgimento da Antiguidade Clássica através das letras e artes. Voltaire saudou o mundo literário e artístico da Península Itálica no tempo dos Médicis como prenúncio das Luzes. No entanto, até meados do Ottocento, a Renascença como idéia historiográfica era um território inexplorado. Michelet escreveu sobre a grande revolução mental, o descobrimento humano de si e do mundo. Apesar de ter antecipado as formulações de Burckhardt, a este a posteridade associou merecidamente a definição de $R e$ nascimento em termos do desenvolvimento do indivíduo e da descoberta do mundo e do homem. Coube ao historiador suíço a construção desta época histórica, autônoma, com fisionomia própria e coesão interna. Na introdução de A Cultura do Renascimento na Itália, cuja primeira edição é de 1860, alertanos para as inflexões que os leitores - e ele próprio - encontrarão no objeto: "Os contornos espirituais de uma época cultural oferecem, talvez, a cada observador uma imagem diferente, e, em se tratando do conjunto de uma civilização que é a mãe da nossa e que sobre esta ainda hoje segue exercendo a sua influência, é mister que juízo subjetivo e sentimento interfiram a todo o momento tanto na escrita quanto na leitura desta obra" (BURCKHARDT, 1991, p.21). Peter Gay, ao analisar o estilo de Burckhardt, encontra um canal intimista entre o leitor e o tema. A intitulação de seu livro em ensaio evidencia isso, uma vez que este é o gênero mais pessoal que se conhece, criando uma "imagem segura do passado" de difícil re-interpretação das regras pré-existentes (GAY, 1990, pp.131-166).

Construía-se uma interpretação da Renascença e seus homens sob viés cultural, com uma nova percepção de mundo. Esse breve período - o século 
XIX - tornou-se assim celeiro de intermináveis discussões acerca dos cortes espaciais e temporais que delimitam o Renascimento. São diversos os questionamentos que matizam sua força, sua evolução, o poder dos ideais de indivíduos e círculos intelectuais. Indaga-se sobre a cristalização da "esgotante" noção de ruptura renascentista como uma eliminação do afastamento medieval do homem em relação à civitas terrena e ao mundo natural, ou como entendimento de um corte sem resíduos. Contesta-se a postulação de um esquema hermenêutico no plano historiográfico e filosófico, cujo balanço recente foi efetivado por Cesare Vasoli (VASOLI, 2002, pp.3-25).

Surgiram análises partindo deste modelo, como a de Eugénio Garin, que observa a estreita relação entre os homens do século XIX e o mito renascentista. Segundo o historiador italiano, a filosofia renascentista seria confundida com o contexto da Renascença, havendo sobreposição do idealizado ao histórico (GARIN, 1991, pp.9-16). Ambos os tempos se confundem na excentricidade e nas extravagâncias, e a construção do homem renascentista de Burckhardt denota o quão o passado não é simplesmente passado, mas possuidor de uma continuidade no presente. A necessidade de uma referência ao pretérito se realizou em outro momento que refletiu também nova efervescência na consciência humana para o resgate, ou nascimento deste homem renascentista. Essa percepção dos historiadores contribui para uma análise menos teleológica sobre a subjetividade desses indivíduos, enfatizada por Burckhardt, e também para uma relativização da compreensão do homem renascentista como detentor de uma multiplicidade de talentos, cara à historiografia em geral. Uma famosa passagem da obra de Burckhardt evidencia algo anteriormente não percebido pelos homens, seu entendimento enquanto indivíduos em sua gênese espacial italiana: "Na Idade Média (...) o homem reconhecia-se a si próprio apenas enquanto raça, povo, partido, corporação, família ou sob qualquer outra das demais formas do coletivo. Na Itália, pela primeira vez, tal véu dispersa-se ao vento; desperta ali uma contemplação e um tratamento objetivo do Estado e de todas as coisas deste mundo. Paralelamente a isso, no entanto, ergue-se também, na plenitude de seus poderes, o subjetivo: o homem torna-se um indivíduo espiritual e se reconhece enquanto tal" (BURCKHARDT, 1991, p.111).

Essa nova percepção de si acarretaria uma transformação singular no universo material. Reconhecida, a individualidade traria para o homem uma indiferença quanto ao medo da singularidade, de ser e parecer diferente dos vizinhos. Também não haveria na Península Itálica do século XV espaço para falsa 
modéstia ou hipocrisia; o cosmopolitismo era manifestação explícita do mais alto grau de individualidade, expansão das virtudes sem limites espaciais. O desenvolvimento nesse contexto de uma literatura biográfica seria mais um reflexo da glória moderna. Diferentemente das interpretações que observam apenas a celebração suntuosa de indivíduos sobre-humanos realizando proezas gloriosas, Burckhardt aponta os extremos desta individualidade, e os perigos da auto-afirmação. O homem que se orgulhava em cultivar sua personalidade mais característica, na literatura mais interessante ou nas roupas que lhe apresentavam, necessitava de auto-expressão, o que resultava também em agressividade e desumanidade. $\mathrm{O}$ desejo da fama, a necessidade de obter o apreço dos outros para confirmar o pessoal, podiam desencadear tragédias. Os crimes da Renascença seriam fruto da obsessão pela preservação da individualidade (BURCKHARDT, 1991, pp.81-105).

Garin não enxerga este homem "dissipando o véu" de forma tão definitiva, concebendo-o dicotômico entre a liberdade de criação e percepção de suas potencialidades, e a angústia pela insegurança, fruto desta mesma liberdade que outrora não o acometia. Essa nova concepção de mundo contemplava novos e antigos valores. Entretanto, se Garin encontra confusão entre a filosofia renascentista e o contexto histórico da Renascença na obra de Burckhardt, ele também não está livre dos anseios de seu tempo. Sua observação relativa ao homem renascentista carrega implicitamente o pressuposto de uma percepção futurológica, uma vez que o medo do homem renascentista, segundo Garin, decorre de se assumir uma nova perspectiva ante a nova percepção do mundo. Mas perceber a mudança e temê-la não parece ser uma construção típica do homem em questão. Giacomo Marramao argumenta que este ainda não apresentava uma angústia "transindividual" pelo "presente que escapa", o que caracteriza a "autoconstrição civilizatória". Seu senso mundano do tempo forneceria uma visão sincrônica; havia apenas re-estruturação prospectiva do espaço, e não uma racionalização futurológica. Dessa forma o homem renascentista não reage com sofrimento e desorientação; ele toma essa re-estruturação como um dado, e segue adiante (MARRAMAO, 1995, pp.77-156).

Já Agnes Heller, ao olhar para o homem renascentista encontra um ser que não mais projeta um ideal para sua existência, um valor a ser alcançado. A crise deste homem estaria na própria construção do conceito de si mesmo. $\mathrm{Na}$ Antiguidade e na Idade Média haveria a concepção de um homem ideal. Primeiramente com valores como sabedoria, coragem e moderação. Depois, a justiça da cristandade pautada nos pecados capitais guiaria a conduta dos in- 
divíduos. O homem da Renascença viveria a irrealização de sua grandeza e de sua pequenez, não conseguindo constituir mais um ideal que o orientasse como categoria ontológica (HELLER, 1982, pp.9-27).

Outro ponto caro à historiografia diz respeito à versatilidade do homem renascentista. Burckhardt ao mencionar Leon Alberti, encontra neste a personificação da perfeição de tudo que se propusera a fazer, e apesar disto, ele ainda não chegaria perto de Leonardo da Vinci. Menos eloqüente, ainda que não fugindo à regra, Garin afirma que o homem deste período é qualificado com uma multiplicidade de talentos. Buscando uma explicação para a mesma idéia, Agnes Heller defende que a versatilidade desse homem estava no aparecimento da produção "burguesa", e seu nível relativamente baixo de produção. A interpretação é bastante consensual (BURCKHARDT, 1991, pp.117118; GARIN, 1991, pp.9-16; HELLER, 1982).

No século XIX, auge da fragmentação abrupta do conhecimento e dos afazeres em campos específicos, ocorreu a construção historiográfica da Renascença e de seus homens. Este entendimento encontra-se atrelado ao reducionismo das funções do homem nas sociedades mais complexas. O homem da Renascença não parece entender-se como tal; o sapateiro Jean de Léry, o médico Rabelais e o demonólogo Jean Bodin eram comuns no universo das atividades necessárias aos indivíduos daquele tempo. Assim, em nossa percepção é necessário reverter esta lógica interpretativa. A multiplicidade de talentos só existe na medida em que ocorre a multiplicidade das atividades a posteriori do fazer e do conhecer.

Para Eugénio Garin, o homem renascentista sabia que algo novo acontecia, que seu presente configurava-se de forma diferenciada. Diversos fatos corroboram esse entendimento: o domínio do Império Otomano sobre Bizâncio, o conhecimento do grego clássico e os textos da Antiguidade. As invenções tecnológicas também indicam mudanças - um novo saber ou uma nova necessidade do saber -, interpretadas como égide dessa transformação: pólvora, papel, bússola, imprensa. As navegações e os descobrimentos são temas obrigatórios como marcos do início dos Tempos Modernos. Contudo, esses elementos devem ser compreendidos como consequiências de uma nova atuação do homem ante a natureza, significando um afastamento em relação às coisas naturais, e sua nova proposta de responsabilidade e elaboração de outra forma de conhecimento. Interessa-nos entender que a transformação do homem em sua compreensão de si, e conseqüentemente dos elementos externos, acompanha transformações nas próprias relações entre os homens. Como mudan- 
ça maior, iniciava-se a instituição social entendida como "Estado", que desperta, também, grande controvérsia historiográfica.

\section{Estado moderno}

Para Jean-Frédéric Schaub, os historiadores do Antigo Regime interessados no Estado encontram-se sob a injunção das escolhas da escola dos Annales e da historiografia marxista, que negligenciaram no século XX o estudo da política - generalização polêmica, ao pensarmos em vários trabalhos (ANDERSON, 1995; LADURIE, 1994). A isso se soma o relativo triunfo dos regimes liberais - fazendo com que o tema adquira contornos ideológicos -, e um ambiente político e jurídico caracterizado por fenômenos de transferência da soberania, pela sedução do federalismo e pelo horizonte transnacional europeu. Nesse quadro, é grande a dificuldade em lidar com a periodização da história política, refém da classificação tradicional. Durante o século XX, pesquisas apresentam uma Idade Média nacional e burocrática, Tempos Modernos religiosos e feudais, ou uma Época Contemporânea de arcaísmos e resistências. Freqüentemente, em função de um paradigma modernizador, identificase no passado a experiência contemporânea, projeções teleológicas designadas como anacronismos. Sem negar a importância de elementos como a precocidade do stato italiano ou a teoria da soberania de Bodin, Schaub recusa neles o caráter indelével de divisores de idéias e épocas, que não tiveram em seu tempo, mas que uma visão retrospectiva da história lhes concedeu. Questiona o caráter revolucionário da construção jurídica bodiniana de uma soberania fundada no monopólio da lei, e o próprio estatuto da lei no conjunto dos instrumentos normativos do Antigo Regime. Em suma, interroga-se sobre a datação do Estado, supondo que a soberania foi realizada por um processo multissecular de acumulação de forças e direitos por parte da instituição governamental.

O discurso da história é assim reenviado à própria construção do tempo histórico, pela identificação dos tempos, do qual fala o historiador e daquele que pensa reconstruir. A interpretação positivista do passado francês, deixada intacta pela historiografia sócio-econômica, fez com que a história política, ao tornar-se objeto da história, funcionasse como história oficial. Ainda hoje, a descrição do Estado francês sofre para se distanciar do modelo que determina sua gênese pela emergência de um sentimento nacional, ou pela impessoalidade do poder (SCHAUB, 1996, pp.127-141). 
Mais uma vez, o paradigma de interpretação historiográfica surgiu no século XIX. Uma leitura de $O$ Antigo Regime e a Revolução de Alexis de Tocqueville, de 1856, engrandeceu a herança centralizadora da dinâmica revolucionária, situando instituições novas numa tradição de séculos (TOCQUEVILLE, 1982; COSANDEY \& DESCIMON, 2002, pp.137-138). Reduzindo a ruptura, a história política identificou antes da Revolução o anúncio de sua obra. Mas a Revolução não foi algo superficial. Além de muitas transformações, ela inaugurou a autonomia da política em relação às oposições sociais, finalizando a indistinção entre sociedade e governo, e formando plenamente o conceito de Estado na França do século XIX. Tal asserção expressa a distância em relação à retórica política da Idade Moderna como forma acabada de poder institucional. Nesse sentido, para Schaub, o livro de François Furet, embora esvazie a mudança da Revolução na esteira de Tocqueville, identifica nela essa conquista da independência da política (SCHAUB, 1996, pp.144-153; FURET, 1989, pp.145-175).

$\mathrm{Na}$ recusa metodológica de operar uma cisão entre história e teoria política, antropólogos interessam-se por antigos fenômenos sociais e culturais. Essas sugestões justificam uma démarche da análise política das sociedades do Antigo Regime que não passa pela tradicional cronologia da afirmação do Estado. Ademais, Schaub identifica três frentes de renovação: a aceitação dos insumos da história do direito, uma hermenêutica dos textos antigos menos evolucionista, e a abordagem da história do Estado como institucionalização da sociedade - mais do que como descrição de instituições.

O quadro é complexo. A obra de Bodin, por exemplo, pode ser objeto de várias leituras. Se o jurisconsulto foi um defensor do absolutismo, seu pressuposto político é interpretado como etapa na formação de uma ideologia, embora esteja sem dúvida ligado às guerras religiosas. Mas se a soberania de Bodin é uma teoria geral do Estado, esse sentido é contemporâneo. A interpretação, anacrônica, concebe a lei como criação do direito positivo, norma jurídica suprema. Mas esse anacronismo requer também uma suspensão do julgamento sobre a datação do Estado, que como vimos aprisiona a análise. No domínio administrativo, é conhecida a interpretação retrospectiva que concebe Bodin como definidor da função pública, a partir da teoria do direito público. Para o jurista francês, a questão consistia em saber se uma pessoa pode possuir um comando, dissociando o ofício do oficial, já que o poder delegado permanecia propriedade do Estado. Os magistrados entre eles o rei - detinham competências, mas os títulos conferidos não lhes pertenciam. Mas Bodin, exercendo funções de um jurisconsulto de seu tempo, não 
operava separação completa entre o ofício e sua pessoa, por exemplo, ao atribuirse vaidoso o pioneirismo na definição da soberania do poder régio, ao pronunciar-se sobre o destino dos oficiais no fim de cada reinado, ou ao impedir o rei de lançar novos impostos para a guerra nos estados gerais de Blois, 1576. Os laços sociais tecidos entre ofícios e instituição monárquica eram muito fortes para que uma teoria da impessoalidade absoluta do poder público pudesse se impor (MONTEIRO, 2003, p.172).

O savoir-faire dos magistrados não era o único limite à expansão de um puro poder público. Bodin também examinou as leis fundamentais, essenciais para a monarquia: a lei sálica, e a inalienabilidade dos domínios da coroa. Nos dois casos, as normas incidiam nas relações entre príncipe e estados, para afirmar o caráter dinástico da instituição régia, e fixar condições do exercício do poder real. Essas disposições desempenharam papel importante no trabalho de impessoalidade da autoridade pública, corroborando a teoria da soberania. Desse modo, segundo Schaub, os historiadores também se equivocam se concebem a teoria de Bodin como mero reflexo de seu tempo, ou apenas uma exaltação do absolutismo (SCHAUB, 1996, pp.153-159).

Entre poucos estudiosos, Michel Senellart rompe com as barreiras cronológicas na análise dos textos, ao verificar como o moderno conceito de governo surgiu de regras anteriormente elaboradas para o regimen medieval, o governo das almas exercido pelos homens da Igreja (SENELLART, 1995). Sem enveredar por uma concepção teleológica da história, pode-se compreender como a visão teórica de Bodin permite imaginar a monopolização pelo soberano do poder de comando pela lei, mesmo que a sociedade política não tenha produzido, propriamente, um Estado. Essa abordagem das estruturas políticas do Antigo Regime assume suas tensões inerentes, evidenciando as fragilidades de uma história política por demais certa de suas conclusões.

Nesse sentido, Schaub defende uma história dos textos políticos em sua acepção cultural, distanciando-se do "fetichismo filosófico". A história sóciocultural indica a necessidade de maior sensibilidade aos conteúdos dos textos. Com efeito, a chamada escola de Cambridge oferece importantes reflexões acerca de um estudo comparativo das obras contemporâneas aos "clássicos", como Quentin Skinner, ou de uma identificação apurada das linguagens políticas, como J. G. A. Pocock. Todavia - não obstante a qualidade dessas análises na utilização do método contextual -, o exemplo de Cambridge e de sua história das idéias políticas não será reproduzido neste artigo, uma 
vez que ampliamos aqui a noção de "política" em direção ao âmbito cultural e filosófico renascentista (MONTEIRO, 2005; SKINNER, 1996; POCOCK, 2003, pp.9-99) $)^{2}$.

Entre a definição da soberania de Bodin e a fundação da soberania nacional pela Revolução Francesa, um Antigo Regime se move, modelando a esfera do público. Nesse âmbito relacional entre poder público e sociedade, não se pode subtrair da história a parte "contratante" da sociedade, no tempo dos monarcas absolutos. Se uma monarquia sacral constituiu uma resposta à dilaceração do corpo místico medieval, é preciso questionar as condições sociais de monopolização do poder no pólo público. Como se sabe, as guerras de religião quebraram o espelho em que a respublica via-se unida como Estado e sociedade, como Igreja enfim. Mas se a pretensão da monarquia ao monopólio das "cerimônias da informação", na expressão de Michèle Fogel, se afirmou com as guerras de religião, a absorção dessa emissão cultural não foi imediata (FOGEL, 1989).

Torna-se oportuno compreender como o Estado nascendo instituía o social, definia hierarquias e garantia a esfera da intimidade, mas também como agentes sociais representavam status, interiorizando novas legitimidades e hierarquias. Entende-se que a abstração do poder, sua secularização e a objetivação da coisa pública fundaram o Estado. Mas como efetuar essa caracterização, quando os negócios privados e as funções públicas não se separavam? A escola neo-cerimonialista de Ralph Giesey descobriu nas grandes cerimônias a expressão da legitimação sagrada da realeza (GIESEY, 1987). Esta análise é criticada por Alain Boureau, ao demonstrar a necessidade de contextualização social e política de cada celebração organizada, observando também que a exaltação transcendente do rei inspirava-se na liturgia cristã (BOUREAU, 1988). Sabe-se desde Kantorowicz, que a dupla natureza do rei era a condição simbólica e jurídica da definição do Estado, etapa essencial no processo de abstração da função e garantia de sua permanência. Mas a dialética das dignidades e de seu titular não era limitada ao caso do rei bicorporal, sendo verificada em vários estratos sociais, e com muita confusão entre as esferas, como vimos

${ }^{2}$ Isso não é feito por Skinner, ao comentar Bodin - lido apenas na tradução para o inglês - como expoente máximo da utilização do moderno conceito de Estado, constitucionalista em algumas obras, absolutista em outras, reproduzindo em seu livro visões retrospectivas da história política (SKINNER, 1996, pp.513-572). 
no caso do próprio magistrado Jean Bodin. A progressiva abstração do exercício das funções públicas deve ser analisada a partir do estudo das lógicas sóciopolíticas que comandavam seu investimento por pessoas e famílias, e não apenas pelo prisma do poder monárquico (KANTOROWICZ, 1998).

Longe de ter domesticado os poderes hostis (feudais, eclesiásticos, comunais), a monarquia se construía à medida que se construíam outros poderes. Essas construções simultâneas formavam o substrato do Estado, pensado em termos organicistas e corporativos. Ao mesmo tempo, a constituição histórica de uma territorialidade da monarquia permite saber como se constituía um espaço do rei, público e permanente. A lei fundamental em torno da inalienabilidade não remete aos registros de teologia moral da Idade Média. O sistema feudal traduzia o suporte territorial em redes de fidelidades, e o rei medieval não era o cume dessa pirâmide, embora desempenhasse papel simbólico. Portanto, a sinopse do Antigo Regime, vista pelo pólo monárquico, seria precisamente o trabalho da instituição do rei como árbitro, pelo triunfo ideológico da imortalidade do rei e pela afirmação jurídica da inalienabilidade do domínio (SCHAUB, 1996, pp.159-170).

Não obstante, durante o Antigo Regime, a "instituição política da sociedade" contou com agentes a serviço do rei, encarregados de acelerar um processo de desvendamento social: juristas, engenheiros, cientistas, cartógrafos, intendentes, censores, produziam uma cultura desligada da herança teológica medieval. Nesses movimentos, emergia a combinação entre persona do rei, especialistas e sociedade. Era a difusão cultural de outra relação com o mundo material, através de práticas técnicas - lembremos da nova atuação do homem ante a natureza na Renascença. Entre tantos, destacamos os alquimistas, como emblema a expressar essa nova relação "laica" com a matéria, comparáveis ao apelo posterior a uma tecnologia do exercício da autoridade política. Joël Cornette evoca a hipótese de substituição da alquimia pela física moderna, em meados do século XVII, junto à monarquia. Entre Catarina de Médici e Luís XIV, produziu-se um modelo no qual, para o Estado, verdade e segredo - ou mistério - tinham partes ligadas (CORNETTE, 1994, pp.475-505; SCHAUB, 1996, p.176). O exemplo alquimista evidencia a lacuna da reflexão de Schaub, no referente à consideração de aspectos culturais e históricos pertinentes a cada concepção do poder. Embora o historiador francês indique a procedência da abordagem - especialmente pelo contato entre política e literatura -, sua preocupação em desmistificar paradigmas da história política deixa-o refém, ele também, do tema do Estado em sua feição legislativa e institucional. Contudo, se não existia Estado na acepção contemporânea, existiam outros tipos de Estado, ou outras idéias do 
poder, já que uma das boas idéias desse balanço historiográfico consiste em apresentar o poder monárquico em relação à sociedade. Tendo em vista esse âmbito relacional, trata-se de confluir a cultura renascentista e o poder soberano na França do século XVI.

\section{No reino do amor}

Ao enveredar pelo ambiente intelectual da monarquia francesa no tempo das guerras de religião, Denis Crouzet identifica, após a eclosão dos conflitos, duas respostas da realeza - não excludentes entre si - às violências interconfessionais. A mais evidente, de matriz humanista, tentava fundar a paz pela tolerância da fé reformada. Provavelmente de fonte erasmiana, foi dominante de 1560 a 1568, liderada pelo chanceler Michel de L'Hôspital, que se esforçou com alguns intelectuais - os politiques, entre eles Bodin - para tornar política uma visão da ordem régia. Além dos ódios, existia a solução da tolerância como preservação do Estado, pois sem um poder dominante, os homens guerreariam ao infinito. O rei devia manter a paz, justificativa da organização social e política capaz de findar os conflitos. Pode-se perceber essa tendência em muitas passagens de Os Seis Livros da República (CROUZET, 1994, pp.205-213; MONTEIRO, 2003, pp.168-172).

Mas havia outra corrente filosófica que convém enfatizar. Os diálogos de Platão também foram admirados fora da escola por ele fundada, formando um platonismo popular e eclético em Alexandria que suplantou o ceticismo da Academia ateniense. Formulava-se assim uma doutrina de idéias transcendentes, com pontos comuns ao neopitagorismo e aos herméticos - teólogos que utilizavam escritos atribuídos ao egípcio Hermes Trimegisto (YATES, 1987, pp.13-18). No século III d.C, padres alexandrinos fundiam ensinos da Bíblia e da filosofia grega a elementos desse platonismo. A escola, denominada depois neoplatônica, transmitiu sua herança à posteridade. Nela, Plotino concebia um universo hierárquico no qual o Deus transcendente ou Uno, descia por vários graus ao mundo corpóreo, enquanto uma íntima experiência espiritual permitia à consciência retornar através do mundo inteligível ao Uno supremo, ao passo que o mundo físico era uma trama de afinidades ocultas originadas na alma do mundo (KRISTELLER, 1995, pp.55-60).

Embora elementos do platonismo medieval tenham sobrevivido no Renascimento, novos aspectos surgiram pelo encontro com a cultura bizantina. Paul Kristeller não considera o platonismo renascentista parte do humanismo, 
atribuindo-lhe significado próprio como filosofia. Impossível detalhar neste breve estudo as atuações de Marsílio Ficino e Giovanni Pico della Mirandola: a primeira versão em latim de Platão e Plotino, a tradução de supostas obras de Pitágoras e do Trimegisto, a síntese entre platonismo, aristotelismo e cristianismo estendendo-se aos árabes e hebreus, a influência da Academia platônica na Europa (KRISTELLER, 1995, pp.61-69; VASOLI, 2002, pp.193-246). Atribuindo à alma humana um lugar central na hierarquia do universo, Ficino concedia expressão metafísica ao humanismo. Sua doutrina do amor espiritual, cunhando o termo amor platônico, tornou-se muito popular. A importância da ascensão da alma a Deus mediante a contemplação ligava-o aos místicos, e a idéia da unidade do mundo garantida pela alma influenciaria filósofos como Giordano Bruno (YATES, 1987). No século XVI, diálogos de Platão eram lidos nas academias italianas, sobretudo em Florença, onde conferências sobre a filosofia do amor eram freqüentes. Obras de Platão e dos antigos platônicos, além das atribuídas a Orfeu, Zoroastro, Hermes e aos pitagóricos, eram editadas em grego e latim. Os escritos platônicos renascentistas também foram difundidos em línguas vernáculas, sobretudo francesa e italiana. Na França, doutos como Lefèvre d'Etaples e poetas religiosos como Margarida de Navarra, valiam-se das idéias de Ficino, no apelo à contemplação e à experiência interior. $\mathrm{O}$ amor platônico tornava-se moda nas academias literárias. A influência do platonismo também ocorria na matemática, apreciada por Platão e seus seguidores, a expressar a superioridade do conhecimento quantitativo sobre o qualitativo, da matemática sobre a física, do platonismo sobre o aristotelismo.

Nesse âmbito, o poder régio francês da Renascença se caracterizava pela capacidade do rei governar como iniciado nos segredos do universo. No sistema neoplatônico de Ronsard, poeta da corte, o universo era regido por uma lei de alternância. Mesmo que o dia seguisse a noite, que as estações se sucedessem, o bom tempo viria após a tempestade. Em 1566, um teórico explicava a imagem Pietas et Justitia - emblema de Carlos IX - a partir de Ficino, que definia o príncipe como aquele que devia, por suas virtudes, ser sábio para guiar o povo aos bons modos, na crença e amor de Deus. As festas da corte no tempo de Catarina de Médici e de seus filhos podiam chocar pela suntuosidade. Mas a diversão civilizada afirmava a virtude pacificadora do príncipe que vivia em tranqüilidade, oferecendo prazeres e diferenciando-se do tirano, que proporcionava opressão, angústias, medos. As festas eram então espelhos da justiça e piedade régias, incluindo os presentes na consagração das virtudes, reflexos da beleza universal cuja sabedoria só o príncipe possuía. Nesse sen- 
tido, festas, quadros, túmulos e poesias organizados na corte Valois atuavam como talismãs, inspirados em teorias neoplatônicas e herméticas do spiritus, como Ficino desenvolveu a partir do lendário Trimegisto ${ }^{3}$.

$\mathrm{O}$ homem era um mundo que refletia o grande mundo. Entre a alma e o corpo do mundo, entre divindades celestes e terrestres, havia o spiritus, difundido no universo, graças ao qual as influências astrais desciam até o homem. A magia catalisava o influxo do spiritus divino em direção às formas sensíveis. A educação principesca, através de Plutarco, visava fazer de Carlos IX um rei filósofo à semelhança dos descritos na República de Platão. Como a força unificadora do mundo era um fogo, a chama da realeza por meio da educação e da ciência devia ser mantida acesa, contra a degenerescência (CROUZET, 1994, pp.213225). Rei filósofo e mago, que se ocupava das ciências da natureza e agia no plano natural, na acepção de Garin (GARIN, 1991, p.134). Contra a violência, uma realeza da harmonia dos contrários se impunha. Para o letrado Loys Le Roy, inspirado em Platão e Aristóteles, o mundo inferior era governado pelo mundo superior que, segundo disposições astrais, tornava os homens inclinados às virtudes, letras ou guerra, numa estação mais que em outra. Deus alternava o Mal com o Bem, para que os homens não fossem dominados pelo orgulho. Os problemas da França eram naturalizados assim pela lógica da instabilidade das coisas humanas, da bonança ao sofrimento, e vice-versa. A harmonia universal era esse movimento pendular incessante, cabendo aos governantes promover a concórdia.

Num mundo religioso dilacerado, o amor neoplatônico era a última defesa contra a ruptura, tentativa de adesão da monarquia ao movimento universal, a esta sabedoria ou prudência que afastava os efeitos astrais, superando os desafios políticos e religiosos, pela harmonia de contrários que assegurava a perpetuação da vida. $\mathrm{O}$ homem era, portanto, ambivalente, definindo-se numa dualidade conservadora das coisas. Os que detinham o poder político deviam atuar segundo essa compensação para atingir o equilíbrio. Catarina de Médici, nos libelos huguenotes, tornou-se uma feiticeira após o massacre de 1572,

\footnotetext{
${ }^{3}$ Entre livros e manuscritos inventariados na morte de Catarina de Médici, encontram-se edições de Platão, de Plotino, livros referidos à teologia hebraica, sobretudo à cabala, além de um sobre as revelações místicas do Trimegisto. Em 1563 ela decidiu construir para Henrique II e ela mesma, em Saint Denis, uma capela funerária em forma de rotunda, símbolo do universo, com quatro estátuas de bronze lembrando as virtudes do neoplatonismo: fortaleza, justiça, temperança e prudência-sabedoria (CROUZET, 1994, pp.225-240).
} 
responsável pelos males da França. De fato, ela pertencia a uma cultura mágica. Na Renascença, poder significava também atração de forças, comunhão com o fluxo vital, parte de um sistema esotérico de conhecimento que condicionava a política. Além dos eventos das guerras de religião, existia uma cultura que aglutinava poder monárquico, neoplatonismo e hermetismo, ou seja, realeza, filosofia e magia. A religião dos últimos Valois era diferente das confrontantes, catolicismo e protestantismo, ao fazer da arte política uma arte mística. Denis Crouzet defende a busca do poder na França da segunda metade do século XVI nas imagens do mundo que seus contemporâneos compunham, em função dos seus sistemas filosófico-metafísicos (CROUZET, 1994, pp.240-253) ${ }^{4}$.

Ao conceber o poder como discurso, o historiador francês explica o massacre de 24 de agosto de 1572 como um sonho perdido da Renascença, e alivia o drama da violência religiosa na França do século XVI, que recebeu outra abordagem, por exemplo, de Natalie Davis (DAVIS, 1990, pp.129-156). Mas resta saber se as idéias neoplatônicas continuavam presentes no tempo das guerras religiosas após o massacre de São Bartolomeu, quando os conflitos entre católicos e protestantes se acirraram, em especial na obra que a historiografia política entendeu como apenas dedicada ao Estado e ao direito ${ }^{5}$. Em 1576 Jean Bodin publicava Os Seis Livros da República. Voltamo-nos assim para essas questões, na interpretação da obra e do próprio Bodin, em especial sobre o primeiro livro, que comporta a teoria da soberania. Ressalta-se que o autor era um dos deputados do terceiro estado na assembléia de 1576, ocorrida no castelo de Blois, e tinha ligações com os politiques - grupo de católicos

\footnotetext{
${ }^{4}$ Essa acepção do poder difere da que classifica Catarina de Médici como discípula de Maquiavel, para quem o príncipe devia aprender a não ser bom, sem se identificar ao mal. Sob esse ponto de vista a monarquia francesa da Renascença estava distante de Maquiavel. Como estavam os príncipes daquele tempo em geral segundo análise de John Law na coletânea dirigida por Garin (GARIN, 1991, pp.17-36).

${ }^{5}$ Henrique III, o rei de Bodin, importou livros mágicos da Espanha, entre eles um sobre o Picatrix, de autoria de um escritor árabe de influência hermética. Segundo Frances Yates, ele foi o centro de um forte movimento religioso ligado aos capuchinhos, com influências no hermetismo francês. No Ballet Comique de la Royne, festa realizada em 1581, pelo casamento do favorito do rei com sua cunhada, a reforma solar e mágica da monarquia francesa ante os tempos difíceis era evidente, concretizada na harmonia da música e da dança. Tempo em que Giordano Bruno, também "hermético", hospedava-se na corte francesa, mantendo intenso contato com o rei (YATES, 1987, pp.63, 206, 229-230).
} 
e protestantes que advogavam a paz política de maneira mais independente das questões religiosas. Pensemos nas possibilidades que Bodin, como homem de seu tempo, usufruiu na composição de sua obra, o que reflete a necessidade de uma construção teórica da organização social legítima aos indivíduos naquele contexto histórico e cultural.

Bodin recorre com freqüência aos homens da Antiguidade. Romanos, gregos, latinos, egípcios, entre outros, fossem poetas, imperadores, jurisconsultos, magistrados, escravos ou mulheres. Também recorre a histórias de famílias, relatos de viajantes e jargões mitológicos. Não obstante, também se vale de homens "modernos" como exemplos. Homens do Império, da Inglaterra, das cidades italianas. Suas menções compreendem uma opinião, um julgamento de valor, ou expressam uma crença na veracidade para confirmar seus argumentos. Em uma passagem, menciona um filósofo grego e um seu contemporâneo: "todavia, não queremos mostrar uma República Ideal como Platão e Thomas More, chanceler da Inglaterra, imaginaram, mas nos contentaremos em seguir as regras Políticas o mais próximo possível..." (BODIN, 2005, p.5) . O jurista em sua obra referencia obras clássicas, mas sua argumentação é direcionada aos homens do seu tempo. Sua percepção de tempo pode ser entendida como sincrônica, uma vez que mistura elementos antigos e novos para interpretar o presente, não criando fantasias futurológicas. Ademais, parece firme em seus argumentos e sistematização, com inúmeras nuances. Não parece um ser dicotômico pelo medo da liberdade, ou angustiado pelo tempo que escapa. O jurista escreve com fôlego, quase oitocentas páginas, e escreve também várias outras obras ${ }^{7}$. De acordo com Marramao, toma os acontecimentos como dados e segue adiante, sem sofrimento ou desorientação. Podemos perceber sua religiosidade, uma responsabilidade interior (MARRAMAO, 1995). Também seu ideal de homem parece ter uma definição:

\footnotetext{
6 "Toutefois, nous ne voulons pas aussi figurer une Republique en Idee sans effect, telle que Platon, \& Thomas le More Chancelier d'Angleterre, ont imaginé, mais nous contenterons de suyvre les reigles Politiques au plus pres qu'il sera possible ..." (BODIN, 1579, p.3). Livro I, capítulo 1, "Qual é o fim principal da República bem organizada". Tradução em andamento de Os Seis Livros da República de Rodrigo Bentes Monteiro \& Walter Marcelo Ramundo.

${ }^{7}$ Entre elas Théatre de la Nature Universelle (publicado após sua morte), Methodus ad Facilem Historiarum Cognitionem (1566), La Démonomanie des Sorciers (1580) e Colloquium Heptaplomeres (1596) (MONTEIRO, 2003, pp.161-164).
} 
“... quando tem sido a questão de dar a fé, tratar a paz, denunciar a guerra, acordar ligas ofensivas ou defensivas, limitar as fronteiras, e julgar as diferenças entre os Príncipes e Senhores soberanos, não se tem jamais incluído os ladrões, nem sua fuga, se talvez isto não é feito por necessidade forçada, que não é absolutamente sujeito à vontade das leis humanas, as quais têm sempre separado os bandidos e corsários daqueles que nós dizemos inimigos justos em feito de guerra, que mantêm seus Estados e Repúblicas por via da justiça, dos quais assaltantes e corsários procuram a reversão e a ruína" (BODIN, 2005, p.3) ${ }^{8}$. Mais adiante acrescenta: "De qualquer modo, viver em amizade e sociedade repartindo igualmente o saque (...) isto não deve ser chamado sociedade nem amizade, nem partilha em termos de direito, mas conjuração, roubos e pilhagens, pois o principal ponto, no qual jaz a verdadeira marca da amizade, seu padrão, é, a saber, o justo governo segundo as leis da natureza" (BODIN, 2005, p.5) . Bodin não opõe homem e Deus, razão e fé. Percebe-se como indivíduo, responsável por seus apetites, direções, num conjunto que parece composto de valores morais de herança medieval, e também neoplatônicos.

Nesse sentido, enxerga as qualidades de uma natureza em sua configuração plural, apresentando um distanciamento imanente em relação a esta. A harmonia melodiosa do mundo vista de cima, visão de um mundo exterior ao homem. Retomando a discussão encetada sobre a historiografia renascentista, assim como não há homem que não represente o seu tempo, também não há homem contraditório em relação a sua época. O que existe é um olhar teórico reducionista quanto às necessidades dos indivíduos em qualquer tempo. Dessa forma as contradições do passado são muitas vezes provenientes de constru-

8 “... quand il a esté question de donner la foy, traitter la paix, denoncer la guerre, accorder ligues offensives, ou defensives, borner les frontieres, \& decider les differents entre les Princes \& Seigneurs souverains, on n'y a iamais comprins les voleurs, ny leur fuite: si peut estre cela ne s'est faict par necessité forcee, qui n'est point subiecte à la diferetion des loix humaines, lesquelles ont tousiours separé les brigans \& corsaires, d'avec ceux que nous disons droits ennemis en faict de guerre: qui maintiennent leurs estats \& Republiques par voye de iustice, de laquelle les brigans \& corsaires cherchent l'eversion \& ruine" (BODIN, 1579, p.1).

9 “ \& quoy quils semblent vivre en amitié \& societé partageans egalement le butin (...), neantmoins cela ne doit estre apellé societé, ny amitié, ny partage en termes de droit: ains coniuration, voleries \& pillages: car le principal poinct, auquel gist la vraye marque d'amitié, leur defaut, c'est à sçavoir, le droit gouvernement selon les loix de nature" (BODIN, 1579, pp.2-3). 
ções de imaginários ulteriores, que terminam por legitimar as contradições vistas em nosso presente, e vice-versa. Em Bodin, não encontramos a angústia parasitária da subjetividade contemporânea. Em meio aos conflitos religiosos, o jurista observa e dialoga, mas também busca uma ação que possa configurar uma pressão para o fim das contendas de seu tempo.

No direcionamento neoplatônico, Bodin recorre aos antigos e aos valores da espiritualidade e da sabedoria, para justificar a harmonia necessária aos homens para uma vida feliz. Mas introduz elementos novos: "É porque os antigos chamavam República uma sociedade de homens reunidos, para viver com felicidade, essa definição todavia tem mais do que é necessário de uma parte, e menos de outra, pois três pontos principais aí faltam, a saber, a família, a soberania e o que é comum numa República" (BODIN, 2005, p.5) ${ }^{10}$. Alma e um Poder soberano em harmonia necessária ao equilíbrio das partes, tendo o Uno como elemento ordenador. Entende-se que este último pode ser visto como o bem absoluto, verdadeiro. Voltando ao texto, percebemos essas três instâncias de forma implícita: família, soberania, coisa pública. Respectivamente, alma, poder e unicidade.

Em outras passagens, Bodin vale-se de fórmulas matemáticas, fascinado com o número três, os estados da França que deviam ser compostos em harmonia pelo poder soberano. Mas é o trecho final que melhor evidencia a conjugação dos valores culturais destacados para o exercício da política, com uma religiosidade especial que contradita interpretações acerca do jurista como pensador laico, protestante, judeu ou cético, por quase não citar o Novo Testamento em sua obra (MONTEIRO, 2003, pp.168-174):

"Tudo que por vozes e sons contrários se compõe uma doce e natural
harmonia, também de vícios e virtudes, de qualidades diferentes dos
elementos, de movimentos contrários, e de simpatias e antipatias liga-
das por meios invioláveis, se compõe a harmonia desse mundo e de
suas partes: como também a República, é composta de bons e maus,
de ricos e pobres, de sábios e loucos, de fortes e fracos, unidos por

10 “C'est pourquoy les anciens appelloyent Republique, une societé d'hommes assemblés, pour bien \& heuresement vivre: laquelle definiction toutefois a plus qu'il ne faut d'une part, \& moions d'une autre: car les trois poincts principaux y manquent, c'est à sçavoir, la famille, la souveraineté, \& ce qui est commun en une Republique" (BODIN, 1579, p.3). 
aqueles que são os intermediários entre uns e outros: sendo sempre o bem mais poderoso que o mal, e os acordos mais que as discórdias. E tanto é assim que a unidade sobre os três primeiros números, o intelecto sobre as três partes da alma, o ponto indivisível sobre a linha, superfície, e o corpo, assim pode-se dizer, que esse grande Rei eterno, único, puro, simples, indivisível, elevado acima do mundo elementar, celeste e inteligível, uniu os três juntos, fazendo reluzir o esplendor de sua majestade e a doçura da Harmonia divina em todo o mundo, a exemplo de que o sábio Rei deve-se conformar, e governar seu Reino" (BODIN, 2005, p.739) ${ }^{11}$.

Aí está o Estado de justiça harmônica entre o divino e a sociedade, em sintonia com poetas da corte e membros da família Valois, bastante diferente do Bodin absolutista ou constitucionalista identificado por interpretações póstumas (FRANKLIN, 1993). Para esse homem renascentista não havia campos distintos do conhecimento. No entanto, há ainda outro aspecto da obra bodiniana relacionado ao poder que merece ser destacado. Diversamente da acepção neoplatônica que remete o jurista a um contexto cultural específico, esse tópico transcende tempos e periodizações da história.

\section{0 poder da família}

Embora utilize jargões revistos pela recente historiografia política como "Estado absolutista" e "burguesia", Norbert Elias, ao enfatizar as relações entre poder, sociedade e indivíduos nos tempos medievais e modernos, não tem como foco a discussão do Estado e o primado da lei. Concebendo a época estudada

\footnotetext{
11 "Or tout ainsi que par voix \& sons contraires il se compose une douce \& naturelle harmonie, aussi des vices \& vertus, des qualités differentes des elements, des mouvements contraires, $\&$ des sympathies \& antipathies liees par moyens inviolables, se compose l'harmonie de ce monde \& de ses parties: comme aussi la Republique est composee de bons \& mauvais, de riches $\&$ de poures, de sages $\&$ de fols, de forts $\&$ de foibles, alliés par ceux qui sont moyens entre les uns e les autres: estant tousiours le bien plus puissant que le mal, \& les accords plus que les discords. Et tout ainsi que l'unité sur les trois premiers nombres, l'intellect sur le trois parties de l'ame, le poinct indivisible sur la ligne, superficie, \& le corps: ainsi peut on dire, que ce grand Roy eternel, unique, pur, simple, indivisible, ellevé par dessus le monde elementaire, celeste \& intelligible, unit les trois ensemble, faisant reluire la splendeur de sa maiesté \& la douceur de l'harmonie divine en tout ce monde, à l'exemple duquel le sage Roy se doit conformer, \& gouverner son Royaume" (BODIN, 1579, p.739).
} 
como processo civilizador, ele rompe com a periodização tradicional, interessado na conduta dos sentimentos humanos rumo a uma direção específica, quando o controle efetivo de terceiros seria convertido em autocontrole de desejos e libido, para sua adaptação a uma estrutura social complexa (ELIAS, 1993, v.2, pp.193-207). A Renascença é vista como momento significativo dessas transformações, no que se refere à organização social em vias de encaminhamento, mas também à produção historiográfica que construiu o conceito de Renascimento sob o prisma de mudança de concepção do indivíduo sobre si mesmo e o mundo. No entanto, esse processo também diz respeito aos monopólios de poucos indivíduos, líderes aptos a exercer atividades reguladoras mediante mecanismos de legitimação, responsáveis pelos demais. Dessa forma, os expedientes utilizados pelas monarquias européias - mormente a francesa - revelavam uma apropriação da intermediação das relações humanas. As lideranças condicionadas por tradições, mas também por novas construções legitimadoras, procuravam atender a esse novo universo de necessidades dos indivíduos.

Nesse âmbito o amor, outrora concentrado na figura do mito universal cristão, era catalisado por indivíduos preocupados em assumir a orientação do "rebanho órfão" da estrutura de poder religioso no início de sua decomposição. A metáfora de Schopenhauer - referente a porcos espinhos que se aproximam e afastam até encontrarem uma distância ideal para aquecerem-se sem se espetar - ilustra o problema das relações sociais. Mediante essa imagem Freud - cuja teoria serviu a Elias - explica a superação da "hostilidade primária" entre os homens na formação de grupos pela força do amor que vincula os indivíduos, como base, instrumento e efeito da autoridade. Para surgir o amor no grupo, era necessária a figura paterna, a compartilhar esse sentimento (FREUD, 1976, pp.52-69). José Brunner afirma que o paradigma edipiano de Freud é um constructo teórico reducionista, ao fazer do desenvolvimento masculino uma norma falocêntrica e autoritária, além de resvalar para a universalização mítica (ROTH, 2000, pp.76-87). Podemos concordar com a crítica, mas no universo francês quinhentista, deparamos-nos com a existência da lei sálica, que regulava a sucessão do trono através dos filhos varões. Considerada a lei mais fundamental do reino, caracterizando uma monarquia mantida pela ordem dinástica, o respeito à lei sálica causou guerras externas - como a dos Cem Anos - e internas - como as religiosas do século XVI.

A proteção paterna, como poder e agregação, também se encontra em $O s$ Seis Livros ..., a mostrar que as estruturas paternalistas e a analogia entre pai e rei eram perceptíveis e naturalizadas naquele mundo. Para Bodin a família 
era a primeira base da sua argumentação de Estado, arcabouço sensível na sua composição filosófica. Segundo Pietro Costa, a família era um microcosmo da representação da ordem política numa escala maior. Da família chegavase à República, e do pai ao rei, numa configuração patriarcal de sociedade (COSTA, 1999, pp.65-80). A família seria assim uma espécie de sintonia fina do Estado harmônico, enquanto o rei-pai, figura masculina como líder e indivíduo, seria o juiz para a manutenção do processo civilizador, no entender de Elias. Como vimos, o homem renascentista concebia-se de forma diferente, percebendo uma mudança e uma necessidade de transformação da natureza que o cercava. Enxergava também o outro de maneira diferenciada, necessitando de mecanismos que estabelecessem novas relações.

Nesse sentido a mudança do homem constituiu na França das guerras religiosas uma necessidade de restabelecer bases de autoridade capazes do retorno à paz e da preservação física dos indivíduos. Para os homens, entre eles Bodin, tratava-se de buscar elementos que reatassem este elo, mediante a memória de um passado social, mas também por uma estrutura da autoridade presente na sua própria composição psíquica. Desse modo, rei, Deus, soberano e pai seriam variações de um mesmo tema, e a adjetivação desta autoridade significava a escala de valores estruturais de uma sociedade, sobretudo no referente à secularização.

Bodin, além das discussões acerca da legitimidade régia e seus mecanismos, operava no sistema dessa estrutura constituinte da autoridade e do poder, a família, negligenciada por comentadores de sua obra ${ }^{12}$ : "A segunda parte da definição de República que nós colocamos, diz respeito à família, que é a verdadeira fonte e origem de toda República, membro principal desta." Mais adiante comenta: "O justo governo do pai e dos filhos repousa no bom uso do poder, que Deus deu ao pai sobre os próprios filhos, ou a lei sobre filhos adotivos, e na obediência, amor, e reverência dos filhos para com seus pais. A palavra poder é própria a todos que tem poder de comandar a outrem" (BODIN, 2005, pp.10, 25) ${ }^{13}$.

\footnotetext{
${ }^{12}$ Por exemplo, na edição de Les Six Livres ... abreviada por Gérard Mairet os trechos sobre a família, presentes nos capítulos 2, 3 e 4 do Livre I, são suprimidos (MAIRET, 1993, pp.65-81).
} 
O poder de comandar emanava primeiramente de Deus, posteriormente do pai que recebeu este poder divino. Aos filhos, cabia obediência e reverência. Assim a autoridade deste pai era suficiente, se bem usada, para comandar os outros. No universo cultural francês a construção da imagem protetora masculina ganhava a confiança de Bodin no referente à autoridade: "O comando dos ménages se prende a quatro forças, do marido sobre a mulher, do pai sobre os filhos, do senhor sobre os escravos, do mestre sobre os serviçais. E o bom governo de toda a República, corpos e colégios, sociedades e lares, depende de saber comandar e obedecer; diríamos por ordem do poder de comandar, seguindo a divisão que nós colocamos" (BODIN, 2005, p.17) ${ }^{14}$.

Poderíamos prosseguir construindo uma apologia à categoria ontológica da família, a função de cada membro - a mãe, os filhos, os servos e os escravos e mesmo suas quantidades precisas. Bodin em seu contexto desestruturado de fundamentações de autoridade e poder - como era o tempo das guerras de religião na França - recorria a esses elementos arraigados no homem de tradição medieval (COSTA, 1999, pp.65-80). Essa referência ocorria no momento da elaboração dos paradigmas do Estado moderno, e do homem renascentista.

Mas amor, famílias, poder e Estado também lembram um conhecido artigo de Eduardo Viveiros de Castro e Ricardo Benzaquen de Araújo sobre a peça de Shakespeare, Romeu e Julieta. Considerando a peça teatral paradigmática, os autores incorporam o afeto na análise das relações sociais, pois em Romeu e Julieta, "direito" e "afeto" não se acham em perfeita oposição complemen-

13 "La seconde partie de la definition de Republique que nous avons posee, touche la famille, qui est la vraye source $\&$ origine de toute Republique, \& membre principal d'icelle". "Le droit gouvernement du pere \& de enfans gist à bien user de la puissance, que Dieu a donné au pere sur ses enfans propes, ou la loy sur les enfans adoptés, \& en l'obeissance, amour, \& reverence des enfans envers les peres. Le mot de puissance, est propre à tous ceux qui ont pouvoir de commander à autruy" (BODIN, 1579, pp.7, 20). O primeiro trecho é retirado do capítulo 2, "Do Ménage, e a diferença entre a República e a família". Desde o século XIII, ménage significava a administração dos bens. Faire son ménage tinha então o sentido de faire ses affaires. No século XIV, a noção abrangia os objetos de uma casa. O sentido moderno surgiu no século XVI, referente à vida material da casa, mormente seus cuidados materiais (REY, 1998, pp.2190-2191).

14 "Le commandemont des mesnages se prend en quatre forces, du mari envers la femme, du pere envers les enfans, du seigneur envers les esclaves, du maistre envers les serviteurs. Et d'autant que le droit gouvernement de toute Republique, corps \& colleges, societés \& mesnages, despend de sçavoir bien commander \& obeir: nous dirons par ordre de la puissance de commander, suyvant la division que nous avons posee" (BODIN, 1579, pp.13-14). 
tar (CASTRO \& ARAÚJO, 1977, pp.130-169). O amor de Romeu e Julieta indicaria uma valorização especial da noção de indivíduo, acompanhada do surgimento de domínios relativamente autônomos - a esfera política, associada ao poder. Na Verona do século XV, Shakespeare narrou os momentos finais da luta entre duas famílias nobres, com sua pacificação, e a consolidação da autoridade do príncipe. Nesse ambiente surgia o amor entre dois inimigos, Romeu e Julieta. O príncipe era um árbitro com posição eqüidistante em relação às facções. A morte dos amantes dissolveu os ódios, e a união das famílias implicou seu fim como entidades autônomas ${ }^{15}$. Para Castro e Araújo, o esquema amor-indivíduo versus sociedade-família não esgota o tema do amor na peça, que atinge a própria identidade individual. No caso limite de Romeu e Julieta, o amor acionaria duas noções de indivíduo: como ser moral autônomo, e como membro da espécie.

Entretanto, o radicalismo do amor teatral e o trágico destino dos amantes, unidos apenas na morte, não excluem a convergência entre o amor de Romeu e Julieta e a consolidação do poder em Verona. Pois a peça de Shakespeare seria também um mito que narra, além da origem do amor, a fundação do Estado. Romeu e Julieta eram indivíduos que só respeitavam a autoridade do príncipe. Os autores comparam então $O$ Príncipe de Maquiavel e a peça teatral. Maquiavel abordaria o político com lógica independente. O mesmo isolamento de domínios estaria em Romeu e Julieta, em direção oposta: o amor, as relações interindividuais, também não se encontravam imersos na lógica relacionada à família. Ao separar os indivíduos das famílias, o amor também retirava delas a autoridade política, concentrada nas mãos do príncipe de Verona ${ }^{16}$. Em síntese, Eduardo Viveiros e Ricardo Bezaquen acrescentam outra dimensão ao indivíduo como ser moral autônomo, possuidor de direitos e

\footnotetext{
${ }^{15}$ Inspirados em Philippe Ariès, para Castro e Araújo o casal Romeu e Julieta seria uma manifestação das "novas formas de família" no Ocidente, com relações internas de afeto. A família conjugal moderna, formada a partir de laços afetivos, individuais, retirarse-ia da esfera política, voltando-se para si mesma e constituindo domínio próprio, do privado, psicológico. Não nos parece ser essa a acepção da família bodiniana, que remete à noção de casa nobre, formando grupos para o estabelecimento da República. Argumentos diferentes de Ariès, que concentra a análise no comportamento familiar, no sentimento de infância, jogos, disciplinas, instituições de ensino, roupas etc (ARIÈS, 1981).

${ }^{16}$ Os autores observam que a maior parte de $O$ Príncipe era dirigida aos principados novos, não hereditários, ou seja, sem ligação com lealdades familiares, dependendo apenas da virtù do governante (CASTRO \& ARAÚJO, 1977, p.163).
} 
deveres, mostrando como essa concepção ocidental possui um aspecto que permite a confusão com a idéia de indivíduo relacionada à espécie. Esse aspecto seria a personalidade, o indivíduo como ser psicológico. A personalidade seria a verdade do indivíduo, mas também indicaria seu papel social. Desse modo o poder, manipulado por indivíduos desvinculados da ordem tradicional, afastava-se da concepção holística do mundo, tanto quanto o amor, que ligava indivíduos independentes da ordem moral-social-religiosa.

A análise estrutural da peça indica diferenças em relação à teoria de Bodin e ao Estado francês da Renascença, como figuram neste artigo. Destaca-se primeiramente a abordagem que descentra o tema do âmbito da lei, do direito e da administração, possibilitando o estudo do poder vinculado a contextos específicos e a sentimentos. Mas a família bodiniana, tal como aparece em Os Seis Livros ..., não é a mesma conotada por Castro e Araújo, pois não se opunha ao poder soberano - outrossim era a sua própria base -, tampouco ao amor, embora esse amor não fosse entendido na acepção individual do estudo antropológico. Dessa forma, se a peça de Shakespeare é considerada um arquétipo, esse caráter modelar não deve ser atribuído à obra de Maquiavel - e nem a Bodin -, pois verificamos aqui um Estado francês em ampla relação à sociedade, dependente de famílias na teoria e na prática. Afinal, como entender as guerras de religião sem as facções familiares Valois Angoulême, Bourbon, Guise, Condé, Montmorency? Disputas que não cessariam com a ascensão de Henrique IV e o fim das guerras, ressurgindo na Fronda durante a menoridade de Luís XIV. Como diria Bodin, a família mais poderosa detém a soberania. Portanto, Bodin escrevia em acordo ao seu reino dinástico e hereditário, diferente das cidades italianas. E buscava em estruturas medievais como a família, os corpos e os colégios, os fundamentos para sua teoria do poder. Desse modo o julgamento bodiniano negativo sobre Maquiavel, presente em Os Seis Livros ..., confunde-se à experiência histórica tumultuada das cidades-estado. Bodin contava com a tradição, para elaborar sua puissance absolue et perpetuelle (VASOLI, 2002, p.341).

Em conclusivo, destacamos a subjetividade da interpretação histórica, e a importância do século XIX na elaboração de paradigmas historiográficos do Renascimento e do Estado. Leituras que concebem Bodin como artífice do conceito de Estado devem ser revistas não somente em sua negação, mas pela remissão do conteúdo de sua obra ao mundo cultural, filosófico e político com o qual ela dialogava - e a separação desses conteúdos já denota a precariedade da análise. Incorporar a cultura ao estudo da política não significa deslo- 
car a discussão, mas compreender de modo adequado concepções de poder vigentes, descobrindo - no caso de Bodin - outras abstrações e secularizações, para além da história política do direito e da administração. $\mathrm{O}$ estado do homem renascentista diz respeito à individualidade, e percebemos um Bodin autor e vaidoso de sua obra, o que por outro lado, punha limites à impessoalidade no exercício de sua função, e de outros agentes sociais - inclusive o rei. O Estado do Bodin da Renascença também falava de um ideal, concretizado no amor neoplatônico e na magia hermética, harmonizando Deus, poder soberano, famílias e pessoas. Tratava-se, porém, de outro amor que não aquele entre indivíduos, bem como de outra família, relacionada aos tempos medievais, ou a todos os tempos, pela analogia entre o pai e o rei. Tratava-se de outro Estado, diferente da acepção contemporânea, mas diverso também do poder concebido por Maquiavel. Mesmo não lidando com o inventário de seus livros, e não tendo explicitado aqui sua biografia, cremos ter fornecido subsídios para tornar menos contraditória a figura do Bodin político, jurista, demonólogo, cético, humanista, neoplatônico. Mediante análise de seu texto, percebemolo fruto de seu tempo, momento em que guerra e refinamento, violência e civilização grassavam entre famílias, poderes, nobres e plebeus. Mas parece que, ao procurar uma solução para esses problemas, Bodin também falou a outros tempos, razão pela qual ele nos desperta grande interesse, a provocar a subjetividade da nossa interpretação.

\section{Fonte}

BODIN, Jean. Les Six Livres de la République. Lyon: Jean de Tournes, 1579, 762 p., (tradução em exercício de Rodrigo Bentes Monteiro \& Walter Marcelo Ramundo).

\section{Bibliografia}

ANDERSON, Perry. Linhagens do Estado Absolutista. São Paulo: Brasiliense, 1995. ARIÈS, Philippe. História Social da Criança e da Família. Rio de Janeiro: Zahar, 1981. BOUREAU, Alain. Le Simple Corps du Roi: l'impossible sacralité des souverains français XVe - XVIIIe siècle. Paris: Éditions de Paris, 1988.

BURCKHARDT, Jacob. A Cultura do Renascimento na Itália: um ensaio. São Paulo: Companhia das Letras, 1991. 
CASTRO, E. B. Viveiros de \& ARAÚJO, Ricardo Benzaquen. Romeu e Julieta e a origem do Estado. In: VELHO, Gilberto (org.). Arte e Sociedade. Rio de Janeiro: Zahar, 1977, pp.130-169.

CORNETTE, Joël. Le Roi de Guerre. Paris: Payot, 1994.

COSANDEY, Fanny \& DESCIMON, Robert. L'Absolutisme en France: histoire et historiographie. Paris: Seuil, 2002.

COSTA, Pietro. Storia della cittadinanza in Europa: dalla civiltà comunale al settecento. Roma/Bari: Laterza, 1999, v.1.

CROUZET, Denis. La Nuit de la Saint-Barthélemy: un rêve perdu de la Renaissance. Paris: Fayard, 1994.

DAVIS, Natalie Zemon. Culturas do Povo: sociedade e cultura no início da França moderna. Rio de Janeiro: Paz \& Terra, 1990.

ELIAS, Norbert. O Processo Civilizador: formação do Estado e civilização. Rio de Janeiro: Zahar, 1993, v.2.

FOGEL, Michèle. Les Cérémonies de l'Information dans la France du XVIe. au XVIIIe. Siècle. Paris: Fayard, 1989.

FRANKLIN, Julian H. Jean Bodin et la Naissance de la Théorie Absolutiste. Paris: PUF, 1993.

FURET, François. Pensando a Revolução Francesa. Rio de Janeiro: Paz \& Terra, 1989.

FREUD, Sigmund. Psicologia de Massa e Análise do Eu. Rio de Janeiro: Imago. 1976.

GARIN, Eugénio. Idade Média e Renascimento. Lisboa: Estampa, 1989.

GARIN, Eugénio (org). O Homem Renascentista. Lisboa: Presença, 1991.

GAY, Peter. O Estilo na História. São Paulo: Companhia da Letras, 1990.

GIESEY, Ralph. Le Roi ne Meurt Jamais. Paris: Flammarion, 1987.

HELLER, Agnes. O Homem do Renascimento. Lisboa: Presença, 1982.

KANTOROWICZ, Ernst. Os Dois Corpos do Rei: um estudo de teologia política medieval. São Paulo: Companhia das Letras, 1998.

KRISTELLER, Paul. Tradição Clássica e Pensamento do Renascimento. Lisboa: Edições 70, 1995.

LADURIE, Emmanuel Le Roy. O Estado Monárquico França 1460-1610. São Paulo: Companhia das Letras, 1994.

MACHIAVELLI, Niccolò. O Príncipe. Rio de Janeiro: Ediouro, 2000. 
MAIRET, Gerard (org.). Jean Bodin - Les Six Livres de la République. Paris: Librairie Générale Française, 1993.

MARRAMAO, Giacomo. Poder e Secularização: as categorias do tempo. São Paulo: Editora Unesp, 1995.

MESNARD, Pierre. L'Essor de la Philosophie Politique au XVIe Siècle. Paris: Vrin, 1952.

MONTEIRO, Rodrigo Bentes. A República de Jean Bodin: uma interpretação do universo político francês durante as guerras de religião. Tempo. Revista do Departamento de História da UFF. Rio de Janeiro: Sete Letras, 2003, v.15, pp.161-177.

Família, soberania e monarquias na República de Jean Bodin. In: BICALHO, Maria Fernanda \& FERLINI, Vera Lúcia Amaral (orgs.). Modos de Governar: idéias e práticas políticas no império português séculos XVI a XIX. São Paulo: Alameda, 2005, no prelo.

PANOFSKY, Erwin. Renascimento e Renascimentos na Arte Ocidental. Lisboa: Presença, 1981.

POCOCK, J. G. A. Linguagens do Ideário Político. São Paulo: Edusp, 2003.

REY, Alain (org.). Dictionnaire Historique de la Langue Française. Paris: Le Robert, 1998, $3 \mathrm{v}$.

ROTH, Michel (org). Freud, Conflito e Cultura. Rio de Janeiro: Zahar, 2000.

SCHAUB, Jean-Frédéric. Le temps et l'État: vers un nouveau régime historiographique de l'Ancien Régime Français. Quaderni Fiorentini. Per la storia del pensiero giuridico moderno. Milano: Dott A Giuffrè, 1996, n.25, pp.125-181.

SKINNER, Quentin. As Fundações do Pensamento Político Moderno. São Paulo: Companhia das Letras, 1996.

VASOLI, Cesare, (org.). Le Filosofie del Rinascimento. Milano: Bruno Mondarori, 2002.

YATES, Frances. Giordano Bruno e a Tradição Hermética. São Paulo: Cultrix, 1987. 